As a result of a comprehensive analysis of the studied existing interpretations of the essence of labor potential of the enterprise, their list is systematized into four main approaches to the specification of the semantic basis of this term.

On the ground of the application of basic logical methods of concept generation (analysis, synthesis, comparison, abstraction, generalization), the essential features of this term are identified in terms of content of actions and essential certainty: a set of existing and potential capabilities and abilities of employees; self-realization, effective use, increase and development of opportunities for employees in employment; promoting the achievement of strategic goals of enterprise development.

To formulate the definition of "labor potential of the enterprise" the following is suggested: first, a combination of the above three essential features of the labor potential of the enterprise; second, the inclusion of a sign of the possibility of manifestation in the latest changing conditions of the socio-economic environment of enterprises; third, grounding at the same time on the interpretation of the basic concept of "potential"; fourth, taking into account the peculiarities of the four main approaches to the specification of the semantic basis of the term.

Based on the above provisions, the essence of the labor potential of the enterprise is formulated, whose difference from the existing ones is a comprehensive consideration of its essential features in terms of essential definition and content of actions, as well as taking into account the possibility of manifestation in the latest changing socio-economic environment.

Key words: potential, potential of the enterprise, labor potential of the enterprise, essential characteristics of labor potential of the enterprise, signs of labor potential of the enterprise.

UDK 640.5.658

DOI: 10.30977/ETK.2225-2304.2021.38.0.45

\title{
ORGANIZATIONAL AND ECONOMIC MECHANISM AND DEVELOPMENT STRATEGY FOR THE RESTORATION OF THE LIBERATED TERRITORIES OF AZERBAIJAN IN THE POST-CONFLICT PERIOD
}

MAMMADOV M., Doctor of Economic Sciences, Professor.

E-mail: m.m.asirli@mail.ru, ORCID ID: 0000-0002-5327-2507

MAMMADOVA F., Candidate of Economic Sciences, acting assistant prof. 9395

E-mail: fidanmammadova12@hotmail.com, ORCID ID: 0000-0003-0384-

GANIYEV Kh., Doctoral candidate.

E-mail: Khanlar.ganiyev@ gmail.com, ORCID ID: 0000-0003-2435-0833

NAGDIYEV O., Doctoral candidate.

E-mail: naqdiyev@mail.ru, ORCID ID: 0000-0002-8894-1272

Azerbaijan University of Architecture and Construction, Ayna Sultanova str., 11, Baku, Azerbaijan.

Abstract. The article examines the economic reforms carried out in Azerbaijan, the goals outlined by industries according to Strategic Plan of the "Strategic Road Map for the National Economy and Main Sectors of the Economy", aimed at implementing these reforms, development 
strategies, and reforms carried out in accordance with State Programs. The importance of these reforms in the national economy sustainable and constant development has been noted. The article describes the development of the non-oil sector in the framework of general, sectoral and regional programs adopted in Azerbaijan to achieve sustainable development, diversification of the economy, development of infrastructure aimed at ensuring socio-economic development. Thus, the level of gas supply infrastructure in the regions, the level of gasification, the level of industrialization, the creation and development of infrastructure in existing industrial zones, as well as the implementation of clustering measures were reviewed and determined that in 2019, 46 enterprises were registered as residents and more than 8,000 permanent jobs were created. At the same time, during the 4th stage of the industrial revolution, the implementation of innovations in the field of ICT in Azerbaijan, new opportunities for sustainable development of the country as a result of digitalization and the formation of a digital economy were created.

Also, the importance of restoring the liberated territories of the country, assessing the current state of the economy, determining the priorities of the sectors and establishing an organizational-management mechanism that ensures the gradual development of these areas in a timely manner were studied in detail.

The relevant state decrees, defining measures that need to be taken to ensure the restoration and development of the Upper Karabakh and Kelbajar-Lachin regions and adjacent territories, were also considered and analyzed, specific directions of the organizational and management mechanism to ensure their implementation were specified.

Key words: reforms, strategic roadmap, politics, sustainable development, regional development, development strategies, restoration, development concept.

Formulation of the problem. Effective integration into the world economic system depends on the implementation of effective economic reforms that ensure the sustainable development of each country and the Development Strategies, State Programs, Action Plans that are part of it. The study of the experience of developed countries in this area shows that countries that develop Development Strategies in line with modern requirements, ensure its implementation and carry out appropriate reforms in stages, achieve sustainable development. Azerbaijan is also developing and implementing new reforms in priority areas of the economy and the strategies that condition these reforms.

One of the key areas is the reconstruction of the infrastructure of the Upper Karabakh and Kalbajar-Lachin economic districts, as well as all sectors of the economy of the adjacent regions, is part of the process of restoring our country's territorial integrity. Given the importance of the region's economy, it will become a new and crucial stage in the country's economic development, assuring the gradual and subsequent expansion of this territory and making it an essential element of Azerbaijan's economy. 
Analysis of recent research and publications. Purpose of the Article Thus, as a result of the economic policy pursued in Azerbaijan over the past 15 years, necessary measures to diversify the economy, ensure dynamic and sustainable development of the non-oil sector, accelerate the development of competitive industries in all areas during the implementation of Azerbaijan's Strategic Road Map 2016-2020 The goal is to ensure the sustainable development of the national economy until 2025 and to strengthen its competitiveness during this period. At the same time, the main goal for the period up to 2025 is to improve social welfare and build a strong competitive and inclusive economy based on development of high technology and the economy most optimal and suitable structure, which will ensure the highest human index. To this end, the country continues to implement measures covering all sectors of the economy in accordance with the above-mentioned development concepts in order to achieve sustainable development of the economy and, consequently, to ensure the production of competitive products. As a result, the implementation of targeted measures to diversify the economy in our country has accelerated the development of the non-oil sector in recent years. The measures taken to liberalize the business environment in the country have been of particular importance in ensuring the sustainable development of these sectors. With the aim to achieve the objectives and goals set out in the Strategic Roadmap for the national economy and its 11 economic sectors, the priority of measures to ensure economic reforms in the country should be identified in stages, evaluated and their implementation in a logical sequence $[1,5,12]$.

Formulation of the goals of the article. Systematic conceptual approach and analytical generalization methods were used in the research process. The research database consists of the materials of the State Statistics Committee of the Republic of Azerbaijan, the Ministry of Economy of the Republic of Azerbaijan, the scientific-practical journal of Construction Economics and Management and the International Scientific Conference - Infrastructure Support of Diversified Economy.

Presentation of the main research material. Reforms and development strategies in Azerbaijan are the basis for sustainable development. The economic policy developed and implemented by the government is a guarantee for achieving the abovementioned goals and sustainable development of the country. These goals achievement is 
possible due to implementation of measures aimed at accelerating the development of the non-oil sector, diversification of the economy, sustainable and balanced socio-economic development of the regions within the general, sectoral and regional development programs adopted in the country, which has special significance.

For this purpose, one of the priority directions envisaged in the four state programs designed to promote socio-economic development of the Republic of Azerbaijan regions for 2004-2023 is the implementation of measures for the reconstruction and development of energy infrastructure in the country's regions is made. As a result of these measures, 56.2 thousand $\mathrm{km}$ of gas pipelines have been laid and repaired in the regions over the past 15 years, more than 1,800 settlements have been supplied with natural gas and the level of gasification in the regions has increased from 41 to $93.2 \%$ [3].

Analysis of the final report for 2019 of the fourth program on socio-economic development of the regions covering 2019-2023, including the state programs that play an important role in the implementation of economic reforms, development strategies and their implementation, shows that during this period the country 61 settlements and 37 new housing estates were gasified, as a result, 15,338 subscribers were provided with natural gas and the total level of gasification in the country reached $96 \%$. The analysis of the mentioned state program shows that the newly laid or overhauled gas pipelines were 1376.7 and $487.7 \mathrm{~km}$, respectively, and these measures were effectively implemented in the economic regions. Thus, 128.7 and $84.4 \mathrm{~km}$ of newly built and overhauled gas pipelines in Baku, respectively; Absheron 90, 28.58 km; Ganja-Qatar- 342.57, 104.32 km; Sheki-Zagatala - 84.24, 15.15, 9.99 km; Lankaran - 60.32, 59.97 km; Guba-Khachmaz - 281.37, 33.19 km; Aran - 395.8, $109.3 \mathrm{~km}$; Upper Karabakh - 0.2.29 km; Mountainous Shirvan - 143.61, $55.81 \mathrm{~km}$ and in the last 15 years more than 1800 settlements have been supplied with natural gas. Coincidently, special attention is given to the industrialization and non-oil industry development, which is an integral part of the policy of economic diversification in Azerbaijan. For this purpose, the "State Program for the Development of Industry in the Republic of Azerbaijan for 20152020 " was developed and currently the implementation of this program has ensured the creation of new value-added industries, raised the level 
of self-sufficiency in many industrial products. in turn, has a significant impact on the emergence of sustainable development in the country $[2,8$, 9]. To this end, to ensure the diversified development of the country's industrial sector in 2019, support the creation of new processing industries, production of export-oriented and import-substituting competitive science-intensive products, application of innovative technologies, creation of modern infrastructure in existing industrial zones, appropriate measures are also being taken to support clustering and the efficient operation of industrial enterprises. Implementation of these measures is considered as one of the main objectives of the Public Investment Program, but at the same time sustainable and balanced development of the country's economy, especially the non-oil sector, regional development, ensuring economic security, systematic and effective implementation of investment projects aimed at environmental protection, is one of the main goals of the program. Investment programs are prepared in accordance with the goals and directions of socioeconomic development of the country. Thus, in preparing the investment program for 2019, in accordance with the country's socio-economic development of, the development of infrastructure and ensuring their sustainable use, stimulating investment in the non-oil sector and regional development, optimal distribution of investment between regions, implementation of investment priorities in social spheres directed.

At the same time, the study of the above report shows that in 2019, the implementation of measures in various sectors of industry continued. One of the mechanisms aimed at industrial development is the creation of industrial parks and industrial districts, as this year 46 enterprises were registered as residents. started production and as a result, more than 8,000 permanent jobs were created.

One of the main goals of economic reforms in the country is to create a modern infrastructure in the economy. The study of implementation of the above-mentioned development strategy, state programs in the field shows that the infrastructure of the country's economy is constantly modernized, advanced modern infrastructure is created. During the fourth stage of the industrial revolution, our country's favorable geographical location, rich use of rich natural and human resources creates new opportunities for sustainable development of the country as a result of international ICT innovations, digitalization 
and the formation of the digital economy [4, 6, 7, 10]. In addition, the "Strategic Roadmap for the National Economy and Key Sectors of the Economy" prepared on the basis of an in-depth analysis of the current economic situation and approved by the Presidential Decree on December 6, 2016 are the main objectives of the Strategic Plan to ensure the sustainability of economic reforms in the country. As a result of reforms in these areas, Azerbaijan has undergone rapid and dynamic development in recent years in terms of economic reforms, and its achievements are highly valued by international organizations and international financial institutions.

Meanwhile, it should be considered that the study of reports on the work carried out and currently carried out under various state programs aimed at socio-economic development shows that the measures envisaged in the development and management of the country's economy. The activities of the sectors are also of particular interest. Therefore, regular reports should be reviewed to assess the level of activity of the private sector within the programs and its coordination with other institutions, and relevant proposals and recommendations should be prepared to improve public-private partnership. Coordinated activities of the public and private sectors in the implementation of measures envisaged in the state programs to ensure the achievement of the goals set for the development of sectors in the Strategic Roadmap to ensure the diversified development of the country's economy, which ultimately forms the basis for a strong economy. These areas of activity play an important role in attracting local and foreign investment, modern technologies and the effective use of modern management practices to create enterprises that produce competitive products and ensure their production of competitive products in accordance with international standards. It should be noted that the sectoral programs and four state programs for 2004-2023, aimed at developing the infrastructure of the economy of the country's regions, provide for a wide range of measures, which determine the areas of activity of the sectors. In order to achieve the above-mentioned goals, the state programs prioritize the implementation of measures to improve the infrastructure of the country's non-oil sector by ensuring the interaction of public and private sectors, ensuring rapid development of entrepreneurship, stimulating export-oriented production, increasing employment. They are aimed, 
among other factors, at the development of the country's economy and the acceleration of its effective integration into the world economic system. In all four programs aimed at socio-economic development of the regions, measures are being implemented in stages in the field of infrastructure, roads and transport, electricity, gas and heat supply, which are important in improving the infrastructure of the economy of economic regions. In our opinion, the role of coordinating the activities of both public and private sectors within the limits of the programs in achieving the goals set out in the 11 roadmaps developed in the Strategic Roadmap for 12 sectors should be regularly assessed, and improvements should be made at each subsequent stage.

A good example of this is that from the early days of the postconflict period, our country has made crucial decisions to enable the successful implementation of measures aimed at the rapid restoration and reconstruction of infrastructure in all areas of the liberated territories' economy.

Goverement's decree "On the establishment of temporary special management in the liberated areas of the Republic of Azerbaijan," signed on October 29, 2020, attests to this fact, and it is a significant step in the strategy's implementation. This degree outlines the highest-priority measures for the first stage, with implementation entrusted to the appropriate government authorities. As a result, the relevant institutions were instructed to provide communication for employees of state enterprises and organizations in the liberated territories, as well as emergency medical care and other services, and to prioritize the implementation of measures to ensure the normal functioning of state structures, as well as the implementation of measures to provide them with electricity, water and natural gas which this is also a crucial direction in carrying out rehabilitation work in these territories, since the infrastructure of all districts of Nagorno-Karabakh and its surroundings water, gas, electricity, and road infrastructure - was entirely destroyed.

This decree, which is an essential element in the initial phase, calls for the restoration of social, domestic, educational, and residential infrastructure, as well as the establishment of production and nonproduction infrastructure at a later stage. Thus, the establishment of commandant's offices in Azerbaijan's liberated territories, as well as special management for each region of the corresponding administrative- 
territorial division, is a necessary organizational and managerial mechanism for reshaping the region's economy, safeguarding the region's economic potential in the post-conflict period, and, as a result, creating favorable conditions for the restoration of the liberated territories by ensuring the protection of the above-mentioned strategic objects.

The legal body which has been entitled "Karabakh Revival Fund" has been established Decree dated on January 4, 2021 to implement the post-conflict construction strategy of the liberated regions in order to ensure the economic development of Upper Karabakh and KalbajarLachin economic regions and adjacent territories within the framework of the country's economic strategy serves as another organizational and economic mechanism for ensuring the socio-economic development of the region while creating favorable conditions for the implementation of the necessary measures for the restoration and development of the mentioned region.

The Karabakh Revival Fund was established to ensure adequate living conditions in accordance with current standards, rebuild and reconstruct all sectors of the economy's infrastructure, organize safe living conditions, conduct out landscaping, and create a thriving situation in the post-conflict region. This organization in turn will play a key role in attracting investment, as well as the financial support and perform measures that are planned for the region's transformation. These initiatives can be executed through public-private partnerships, as well as local and foreign private investments, loans, grants, technical assistance, local entrepreneurs, international financial institutions, and society, in lined with Karabakh's development strategy.

The determination of priorities for the recovery process in the liberated regions, as well as the development of procedures for its implementation, is one of the most essential components, according to a study of international experience with post-conflict reconstruction. In this regard, the damage to the liberated territories is first assessed, and then the liberated territories are cleansed, power, drinking water, irrigation systems, household units, and residential areas are restored within the further stages. In this process, the formulation of new, crucial roadmaps as well as airport rehabilitation measures for humanitarian aid is being undertaken as vital priority. These works are aimed at ensuring 
the safety of the population living in these territories, while providing their connection to the rest of the country, ensuring the necessary security, and raising the standard of living, and they are carried out in stages over a period of time as a preliminary measure for organizing regular production and non-production activities.

As a result, this fund is a well-organized, well-managed structure that will primarily finance and attract investments, as well as carry out promotional activity in the aforementioned areas, both in the country and abroad.

It should also be emphasized that the President of the country is always focused on the implementation of measures to ensure the restoration and development of liberated regions in the post-conflict period. In this regard, on January 6, 2020, a video conference was held by the government dedicated to the results of the 2020. Special emphasis was made at this conference on the fact that Azerbaijan's indicators and achievements as a result of reforms and sustainable economic development are highly recognized in the international reports as a sign of our country's dynamic economic development.

It was noted at the event dedicated to the results of 2020 the newly developed concept of the restoration and development of the liberated lands will allow over a period of time, to carry out appropriate reforms in the Karabakh region, as well as achieve the restoration and development of these territories. Simultaneously, the concept of territorial restoration and development will create favourable conditions for state-led initiatives to develop all sectors of the economy and restore and develop the economic potential of all liberated territories, particularly to attract new domestic and foreign investments in the non-oil sector. At the same time, large-scale restoration work in the liberated areas will operate as one of the drivers of active economic growth when macroeconomic indicators for 2021 are being planned. This is explained by the fact that our country's estimates for 2021 are more positive than those of the International Monetary Fund and the World Bank for Azerbaijan's economy, namely, our country's growth rate is 3.4 percent versus $1.7-2$ percent.

At the aforementioned event in 2021, was outlined a roadmap for the restoration and development of the liberated territories from occupation for the post-conflict period, as well as an organizational and 
managerial mechanism for the development of these territories within the country's economy. These directions are as follows:

- Restoration and reconstruction of road transport infrastructure: Ahmadbayli-Fizuli-Shusha, Togana-Kalbajar-Lachin and HoradizZangilan-Gubadli-Lachin;

- Construction of an international airport at Fizuli, with plans to build a similar airport in the future in the Lachin or Kalbajar regions;

- Start construction of the Horadiz-Fizuli railway, followed by the Fizuli-Shusha railway. In addition to this, it is important to repair of the Horadiz-Agband railway which is critical for the opening of the Nakhchivan corridor which is on the agenda;

- Development of the agricultural sector of the region by organizing the most modern irrigation systems in the liberated territories;

- Restoration and reconstruction of energy supply infrastructure, as well as the establishment of a "green" energy zone in the Karabakh region that can serve as a model for the rest of the globe;

- Rehabilitation and development of the Karabakh region's great tourism potential, as well as the construction of tourist routes;

The essential work on the "Azerishig in Karabakh" project to bring energy to the liberated administrative territories, primarily the city of Shusha, has already begun in these territories. Initially, a diverse range of measures are being implemented to remove power lines from an emergency state. In accordance with the government's Decree dated October 29, 2020 "On the organization of a temporary special administration in the liberated territories of the Republic of Azerbaijan", a power transmission line has been installed to restore power supply to state facilities in the Jabrail region, and furthermore, power supply to strategic facilities in the settlement of Hadrut is provided by a substation in the village of Karakul in this region. In the Aghdam region, 15 kilometers of the "Tartar Ismayilbayli" overhead electricity transmission line has been repaired as part of the decree's execution. $6.5 \mathrm{~km}$ of overhead power transmission line from the "Ergi" substation of the Agdam region was repaired and other relevant activities have been carried out to supply the station with electricity in connection with the deployment of the "Peacekeeping Monitoring Group" in the Marzali village of this region and for uninterrupted power supply of this centre. At the same time, the reconstruction and restoration of a nine-kilometer 
power transmission line from the Gulabird HPP using existing networks is nearing completion in connection with the initial power supply of the Sugovushan village and adjacent territories, as well as the Gubadli and Zangilan regions. It should be noted that, in order to provide electricity to newly created state bodies and objects from various sectors of the economy, a double-circuit overhead power transmission line was laid in a short time from the Shukurbeyli substation to the Hadrut substation in the strategic center of Karabakh - Shusha, resulting in power supply to essential state facilities.

At the same time, the region has a vast industrial raw material potential, which includes many deposits of ore and non-metallic minerals, 167 different types of mineral deposits, fresh groundwater, and mineral waters, and this fact should be considered as an important direction in the concept of the development of the liberated territories.

Along with these measures, the Azerbaijani President highlighted appropriate work on new infrastructure projects and urgent activities continues in all liberated regions for the restoration and reconstruction of liberated territories in the post-conflict period.

Thus, in accordance with the concept of post-conflict development, restoration, and reconstruction of liberated lands, the development of an action plan in these areas, as well as the establishment of an effective organizational and management mechanism to ensure the implementation of these activities in accordance with the established sequence and stages, will play an important role in ensuring the development of the economy of adjacent territories of Upper Karabakh and Kalbajar-Lachin, as an integral part of the economy of the whole country.

It should be noted that the ongoing reforms and state programs, development concepts, strategies and plans implemented in Azerbaijan and the sustainable economic development achieved and strengthened as a result of comprehensive measures to ensure macroeconomic stability in the country is highly valued by international economic and financial organizations. Necessary decisions have been made to diversify the economy in Azerbaijan, ensure the development of the non-oil sector, stimulate the production of competitive production, improve the investment and business environment, constantly improve the regulatory environment of the business environment to modern standards, support the private sector. The annual improvement in the results of sustainable 
reforms aimed at the formation, implementation and improvement of the business environment is constantly reflected in the reports of international financial institutions $[10,11,12]$.

In the "Global Competitiveness 2017-2018" report published by the World Economic Forum, the Azerbaijani economy has moved up two places in terms of competitiveness, ranking 35th among 137 countries, and first in the CIS since 2009. In recent years, Azerbaijan results in reports prepared by the World Economic Forum are constantly improving. Thus, according to the "Global Competitiveness" reports, our country has moved up 34 places - from 69th place among 117 economies in 2005 to 35th place among 137 economies in 2017. As a result of these indicators, Azerbaijan has left behind several G-20 member states. Thus, in the Global Competitiveness Report 2017-2018, Indonesia, which is a member of the G-20, ranks 36th, the Russian Federation 38th, India 40th, Italy 43rd, Mexico 51st and Turkey 53rd, South Africa is 61st, Brazil is 80th and Argentina is 92nd. According to the Global Competitiveness Index, Azerbaijan ranks higher than the neighboring countries as the most competitive economy in the region, but in the report, the countries of the region, Georgia, rank 67th, and Armenia 73 (Fig. 1).

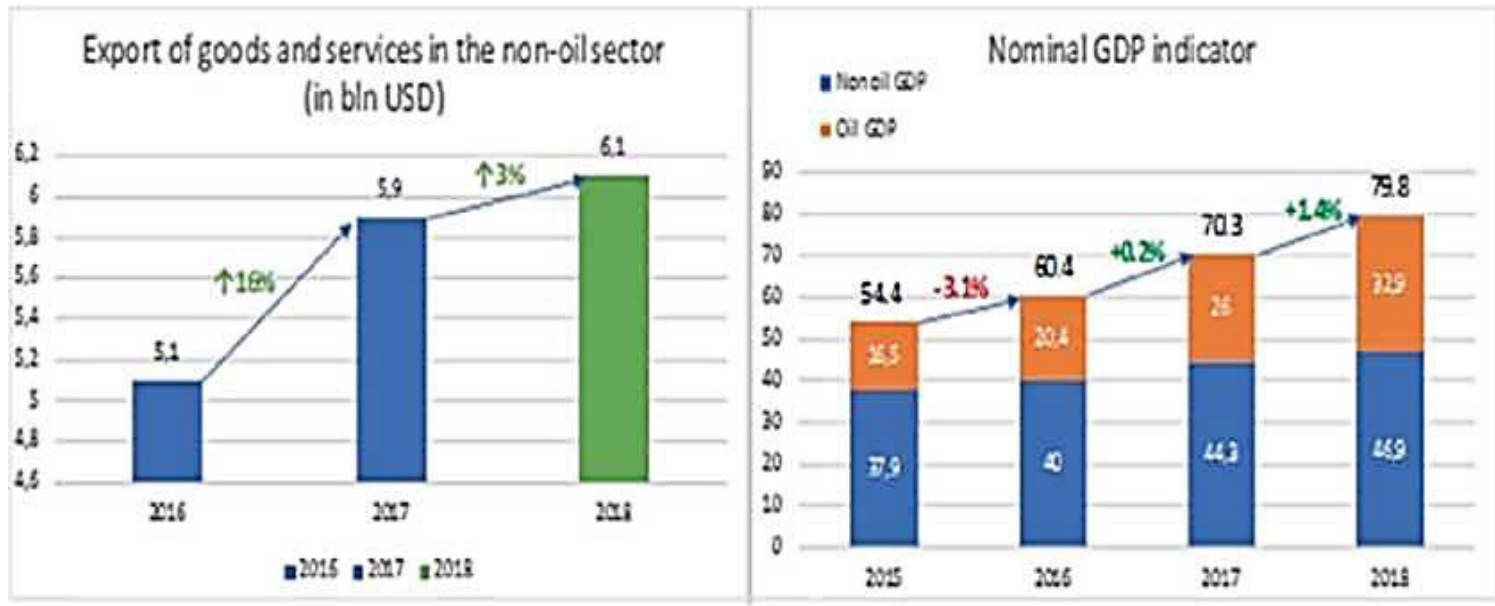

Fig. 1. Azerbaijan international rankings

The "Global Competitiveness Report 2018/2019" lists Azerbaijan as the country with the highest level of social equality in the world. According to the level of electricity supply to the population, Azerbaijan has risen to the first place in the world with a maximum score of $100 \%$. 
According to the report, Azerbaijan ranks 31st among 140 countries in the ranking of business dynamics (Fig. 2).

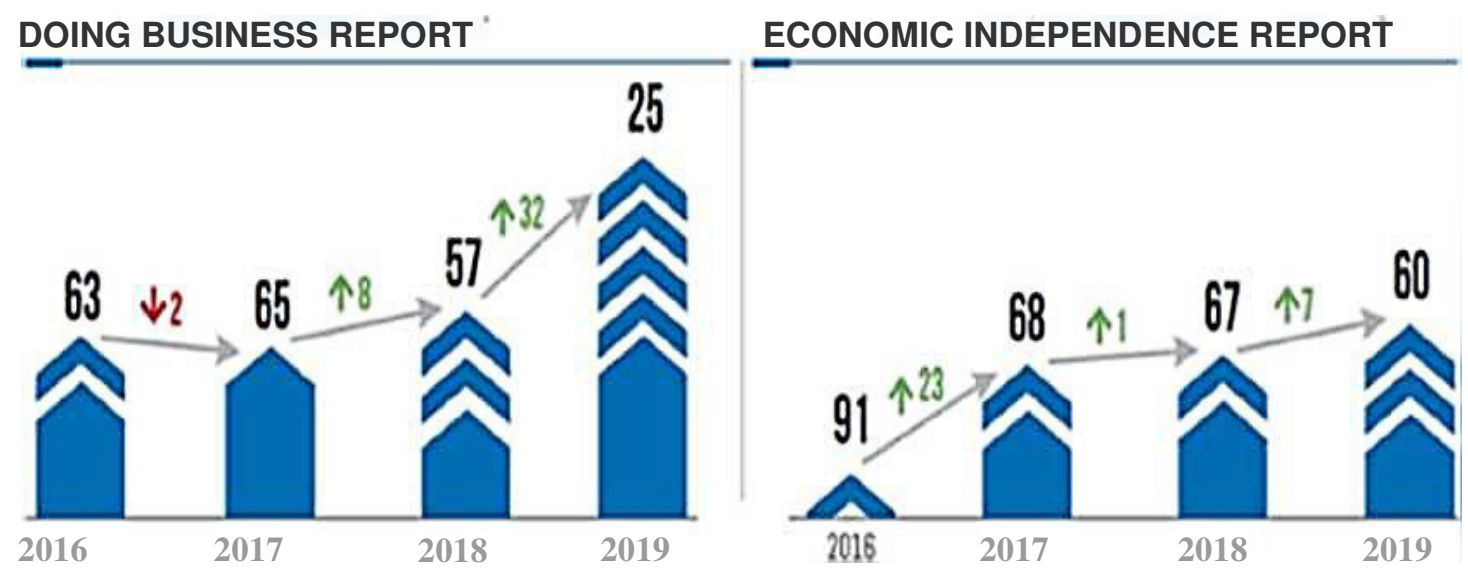

Fig. 2. The results of reforms in Azerbaijan

Reforms implemented in the country by the government within the framework of state programs, development concepts, strategic development plans have ensured that Azerbaijan has achieved new records in the overall ranking in the "Doing Business 2019" report, and its position on most indicators has risen. In the "Doing Business 2019" report which was published by the World Bank and the International Finance Corporation, our country was included in the list of the 10 most reformist countries in the world and declared the most reforming country in the world.

In the "Doing Business 2020" report, the continuous implementation of reforms in the above-mentioned areas in our country was assessed with 78.5 points, and Azerbaijan rose from 34 to 28th place among 191 countries. As a result of the progress made in this position, our country has again been assessed by the World Bank as "one of the 10 most reformist countries in the world."

Thus, it should be noted that these assessments of the International Financial Institutions are a real result of sustainable reforms implemented in Azerbaijan in recent years in the framework of the above Development Strategies, State Programs, Strategic Plans.

Results. We believe that the measures taken as a result of the carried-out reforms in the country and implemented development strategies will allow to achieve the following organizational, managerial and socio-economic advantages: 
- Ensures the diversified development of the country's industrial sector; Ensures sustainable development and competitiveness in the industrial sector

- Ensures the implementation of targeted projects in the non-oil sector

- Allows wide application of innovative technologies

- Creates conditions for the creation of modern infrastructure in industrial zones, as well as to support the effective operation of clustering

- Ensures sustainable and consistent implementation of investment projects in the field of environmental protection;

- Development of business environment, creation of business incubators will stimulate the development of economic regions of the country;

- Sustainable economic reforms implemented within the framework of state programs, development strategies and concepts have resulted in ensuring macroeconomic stability;

- The state regulation of entrepreneurial activity, the application of advanced methods in reforms is highly valued by the World Financial Institutions, which allows us to assess it as a real result of the regular and sustainable implementation of reforms in Azerbaijan.

The results obtained from this research can be used while preparing of Strategic Development Plans of relevant organizations and institutions.

The study shows that the reforms implemented in various sectors of the economy of Azerbaijan form the solid basis for sustainable development.

\section{References}

1. Strategic roadmap for the national economy and key sectors of the economy. (2016). Strategic plan, presidential decree of 6 December 2016. Retrieved from: https://www.turan.az/ext/news/2020/1/free/analytics/en/121631.htm

2. Infrastructure provision of the diversified economy: main trends and directions of development. (2019). In: Materials of the international scientific conference 2019. Publishing and Printing Center, AzUAC, Baku. Retrieved from: https://unctad.org/system/files/official-document/der2019 en.pdf 
3. State program of socio-economic development of the regions of the Republic of Azerbaijan in 2019-2023. (2019). 9-month report for 2019. Retrieved from: https://www.azernews.az/nation/161283.html

4. Economics and management of construction. (2019). Sci Pract Mag (3), Baku-2019.

5. Kozachenko, H., Onychshenko, S., Masliy, O. (2018). Region building complex social and economic security threats. International Journal of Engineering \& Technology (UAE), 7(3), 215-218. https://doi.org/10.14419/ijet.v7i3.2.14405.

6. Sivitska, S., Vartsaba, V., Filonych, O. (2018). Building's energy-efficient renovation investment. International Journal of Engineering \& Technology (UAE), 7(3), 408-412. https://doi.org/10.14419/ijet.v7i3.2.14562 AQ1.

7. Onyshchenko, V., Sivitska, S. (2014). Alternative energy developing investment support in terms of energy dependence. Economic Annals-XXI, 9/10, 34-37.

8. Onyshchenko, V., Sivitska, S., Cherviak, A. (2020). Building's reconstruction within the new educational space project in Ukraine. In: Onyshchenko V., Mammadova G., Sivitska S., Gasimov A. (eds) Proceedings of the 2nd International Conference on Building Innovations. ICBI 2019. Lecture Notes in Civil Engineering, vol 73. Springer, Cham. https://doi.org/10.1007/978-3030-42939-3_66

9. Onyshchenko V, Sivitska S, Cherviak A (2018) Construction industry in Ukraine credit analysis. International Journal of Engineering \& Technology (UAE), 7(3), 280-284. https://doi.org/10.14419/ijet.v7i3.2.14420

10. Drobyazko, S., Bondarevska, O., Klymenko, D., Pletenetska, S., Pylypenko, O. (2019). Model for forming of optimal credit portfolio of commercial bank. Journal of Management Information and Decision Science, 22(4), 501-506.

11. Iasechko, S., Haliantych, M.K., Skomorovskyi, V.B., Zadorozhnyi, V., Obryvkina, O., Pohrebniak, O. (2020). Contractual relations in the information sphere. Systematic Reviews in Pharmacy, 11(8), 301-303.

12. Svistun. L., Glushko A., Shtepenko K. (2018). Organizational aspects of development projects implement at the real estate market in Ukraine. International Journal of Engineering \& Technology (UAE), 7(3), 447-452.

13. On the organization of a temporary special administration in the liberated territories of the Republic of Azerbaijan. Decree of the President of the Republic of Azerbaijan dated October 29, 2020. (2020). Baku. Retrieved from: http://www.eqanun.az/framework/46229

14. Materials of the meeting at the end of 2020. January 8, 2021, Baku 2021. Retrieved from: https://en.president.az/articles/49933

15. Karabakh Revival Fund. Decree of the President of the Republic of Azerbaijan, dated January 4, 2021. (2021). Baku. Retrieved from: https://president.az/articles/49876. 


\section{ОРГАНІЗАЦІЙНО-ЕКОНОМІЧНИЙ МЕХАНІЗМ ТА СТРАТЕГІЯ РОЗВИТКУ ВІДНОВЛЕННЯ ВИЗВОЛЕНИХ ТЕРИТОРІЙ АЗЕРБАЙДЖАНУ У ПОСТКОНФЛІКТНИЙ ПЕРІОД}

МАМЕДОВ М., доктор економічних наук, професор.

E-mail: m.m.asirli@mail.ru, ORCID ID: 0000-0002-5327-2507

МАМЕДОВА Ф., канд. екон. наук.

E-mail: fidanmammadova12@ hotmail.com, ORCID ID: 0000-0003-03849395

ГАНІСВ Х., канд. екон. наук.

E-mail: Khanlar.ganiyev@ gmail.com, ORCID ID: 0000-0003-2435-0833

НАГДІЄВ О., канд. екон. наук.

E-mail: naqdiyev@ mail.ru, ORCID ID: 0000-0002-8894-1272

Азербайджанський архітектурно-будівельний університет, вул. Айна Султанова, 11, м. Баку, Азербайджан

Анотація. $У$ статті розглядаються проведені в Азербайджані економічні реформи, цілі, окреслені галузями відповідно до Стратегічного плану "Стратегічної дорожньої карти для національної економіки та основних секторів економіки», спрямованих на реалізацію ичих реформ, стратегії розвитку та проведені реформи, щяо здійснюються відповідно до державних програм. Відзначено важливість ичих реформ для сталого і постійного розвитку національної економіки. У статті описується розвиток ненафтового сектору в рамках прийнятих в Азербайджані загальних, галузевих та регіональних програм для досягнення сталого розвитку, диверсифікації економіки, розвитку інфраструктури, спрямованої на забезпечення соціально-економічного розвитку. Так, розглянуто рівень інфраструктури газопостачання в регіонах, рівень газифікації, рівень індустріалізачіï, створення та розвиток інфраструктури в діючих промислових зонах, а також виконання кластеризачійних заходів та визначено, щзо у 2019 рочі 46 підприємств зареєстровані як резиденти та створено понад 8 тис. постійних робочих місиьь. У той же час під час 4-го етапу промислової револючії в Азербайджані відбулося впровадження інновацій у сфері IKT, створення нових можливостей для сталого розвитку краӥни в результаті циирровізації та формування цчифрової економіки. Досліджено важливість відновлення звільнених територій краӥни, оцінки сучасного стану економіки, визначення пріоритетів галузей та створення організаційно-управлінського механізму, щэо забезпечує поетапний розвиток ичих територій.

Розглянуто та проаналізовано відповідні державні укази, щяо визначають заходи, які необхідно здійснити для забезпечення відновлення та розвитку Верхньокарабахської та Кельбаджар-Лачинської областей $i$ прилеглих територій, визначено конкретні напрямки організаційно-управлінського механізму щэодо забезпечення їх виконання.

Ключові слова: реформи, стратегічна дорожня карта, політика, сталий розвиток, регіональний розвиток, стратегї розвитку, відновлення, концепція розвитку. 